\title{
An unprecedented radiological presentation of a pulmonary cement embolism
}

\author{
Nader Chebib, ${ }^{1}$ Martin Cour, ${ }^{1}$ Javier Ruiz Munther, ${ }^{2}$ Laurent Argaud $^{1}$
}

${ }^{1}$ Service de Réanimation Médicale, Groupement Hospitalier Edouard Herriot, Hospices Civils de Lyon, Lyon, France

${ }^{2}$ Service de Radiologie, Groupement Hospitalier Edouard Herriot, Hospices Civils de Lyon, Lyon, France

\section{Correspondence to}

Professor Laurent Argaud, laurent.argaud@chu-lyon.fr

Accepted 11 November 2014

CrossMark

To cite: Chebib N, Cour M, Ruiz Munther J, et al. BMJ Case Rep Published online: [please include Day Month Year] doi:10.1136/bcr-2014208065

\section{DESCRIPTION}

A 49-year-old man was admitted to our intensive care unit for acute respiratory failure following cytomegalovirus pneumonia. His medical history included glioblastoma and percutaneous vertebroplasty (with polymethyl methacrylate) for osteoporotic vertebral compression fractures. Thoracic CT scans showed twisted endovascular material in the right pulmonary artery, as well as bilateral hyperdense emboli (figure 1). These findings were also found on the chest X-ray (figure 2). Importantly, they were absent prior to the vertebroplasty, while a central venous access device was already implanted. Antiviral treatment allowed complete
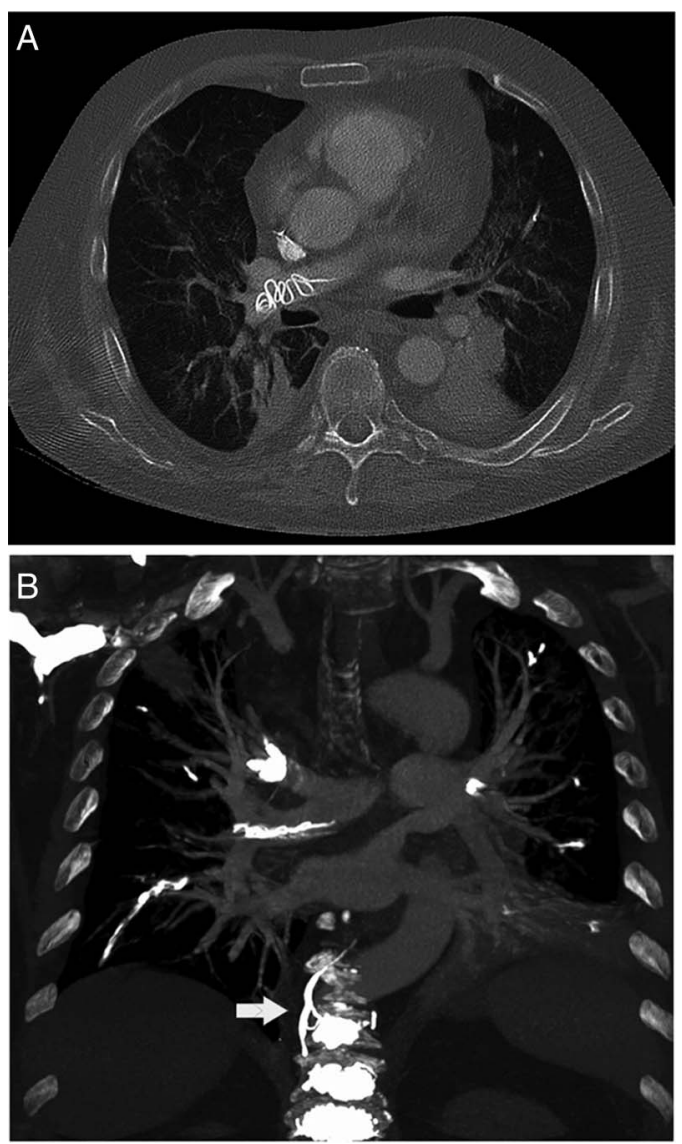

Figure 1 Thoracic CT scan. (A) Presence of a twisted cement embolism in the right pulmonary artery. (B) Coronal reconstruction showing bilateral pulmonary emboli with leakage of cement into the right paravertebral venous system (arrow).

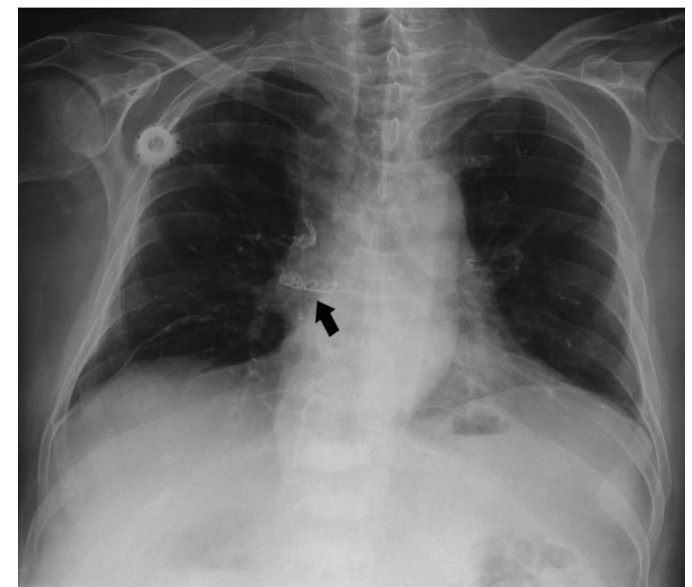

Figure 2 Chest X-ray. Uncommon presentation of proximal cement pulmonary embolism (arrow) associated with bilateral distal radiodense emboli.

resolution of the pneumonia. Therefore, we made a diagnosis of asymptomatic cement pulmonary embolism. No specific treatment was required.

Proximal pulmonary cement embolism is an uncommon complication occurring after vertebroplasty. ${ }^{1}$ It is due to the cement's intravasation into the vertebral venous plexus and its leakage into the pulmonary arterial circulation. ${ }^{1}$ Severe clinical repercussions requiring specific treatment (eg, surgery or material retrieval) remain rare. ${ }^{2}$

\section{Learning points}

- Most cases have no clinical repercussions.

- Conservative management is recommended.

Competing interests None.

Patient consent Obtained.

Provenance and peer review Not commissioned; externally peer reviewed.

\section{REFERENCES}

1 Kim YJ, Lee JW, Park KW, et al. Pulmonary cement embolism after percutaneous vertebroplasty in osteoporotic vertebral compression fractures: incidence, characteristics, and risk factors. Radiology 2009;251:250-9.

2 Krueger A, Bliemel C, Zettl R, et al. Management of pulmonary cement embolism after percutaneous vertebroplasty and kyphoplasty: a systematic review of the literature. Eur Spine J 2009;18:1257-65. 
Copyright 2014 BMJ Publishing Group. All rights reserved. For permission to reuse any of this content visit http://group.bmj.com/group/rights-licensing/permissions.

BMJ Case Report Fellows may re-use this article for personal use and teaching without any further permission.

Become a Fellow of BMJ Case Reports today and you can:

- Submit as many cases as you like

- Enjoy fast sympathetic peer review and rapid publication of accepted articles

- Access all the published articles

- Re-use any of the published material for personal use and teaching without further permission

For information on Institutional Fellowships contact consortiasales@bmjgroup.com

Visit casereports.bmj.com for more articles like this and to become a Fellow 